\section{Challenges in organizing care networks for the elderly in two regions of Brazil}

\author{
Desafios na organização de redes de atenção \\ aos idosos em duas regiões do Brasil
}

\author{
1 Fundação Oswaldo Cruz, \\ Rio de Janeiro, Brasil. \\ 2 Universidade Federal do \\ Piauí, Teresina, Brasil. \\ ${ }^{3}$ Universidade Federal do Rio \\ Grande do Sul, Porto Alegre, \\ Brasil. \\ Correspondence \\ M. Ferasso \\ Universidade Federal do \\ Piauí. \\ Campus Universitário \\ Ministro Petrônio Portella, \\ Teresina, PI 64049-550, \\ Brasil. \\ admmarcos@admmarcos. \\ $a d m . b r$
}

\begin{abstract}
The global trend of ageing populations is present in Brazil. Brazilian society is going through an intensive process of transformation, where young adults are increasingly fewer, thus raising the question of who will take care of the elderly in the 21st Century? There is an urgent need to establish care networks for the elderly, covering primary care, including care with housing (Healthy Housing), as well as to ensure access to secondary and tertiary levels of care, providing early diagnoses and rapid access to treatment. This article reports two Brazilian experiences: the restructuring of a shelter for elderly indigents, with 500 elderly residents in Rio de Janeiro, which involved a broad process of humanization, with strong physical restructuring of the buildings that dated from 1930; and the process of organizing the care referral line for the elderly within the Conceição Hospital Group, in Rio Grande do Sul State, which included a health care complex with diverse health units, encompassing all stages of care: from primary care to the most complex hospital treatment.
\end{abstract}

Health Services Administration; Health Services for the Aged; Health of the Elderly
Luisa Regina Pessôa 1

Marcos Ferasso 2

Lilia Maria Vargas 3

Alcindo Antonio Ferla ${ }^{3}$

\section{Introduction}

The construction of networks for health services or for other public policies is a challenge of enormous complexity, which involves a whole host of issues ranging from the understanding of the needs of the population that is to be assisted, and the definition of the network design (including several units, their different care profiles and their inter-relatedness), to the mechanisms for management, financing and the evaluation of results. In the specific case of service networks for care of the elderly in Brazil, the challenge is all the greater because of the fact that the country is faced with an increasingly aging population.

Population aging is a Brazilian reality. Studies have shown an acute increase in the speed of aging of the populations in many countries and regions in the world, particularly due to the sudden decline in mortality, especially in the period between the 1940s and the 1970s, and the decline in fertility rates of the population 1 .

The main factors that explain this movement in population dynamics reflect, in part, the improvements in health care for younger populations, with little visible evidence of improvements of care to the elderly. Thus, we have a behavior of the elderly population dynamics that concentrated elderly populations and a growing demand for health services, meaning that this pattern does not include improvements in the health of elder people, mainly in developing countries 1 . More- 
over, there is an increasing proportion in the relation between the number of people aged 60 or more, and the number of young adults, becoming an alarming ratio of dependence in caring for the elderly paid for by resources outside the family circle, but it is still quite common for families to care for the elderly with health problems, and this burden falls especially on women, too often those who are themselves elderly 1,2 .

Besides the complexity of the needs and profile of the social context where the elderly population is, it is increasingly common to encounter initiatives aimed at the social rehabilitation of people aged 60 or more and it is a new pattern of cultural and individual needs for that part of the population. If, on the one hand, it expands access to new standards of citizenship among the elderly population, on the other, this group is exposed to new risks and new patterns of disease, such as bone injuries caused by accidents in the home and outside it and also STDs/AIDS, for example 3 .

In the context of the Brazilian health system, the question of care to the elderly is also characterized by some definitions of legal scope. The Brazilian Constitution of 1988 established a new configuration for the national health system, being called the Unified National Health System (SUS) ${ }^{4}$. That constitution defined health as a right of citizenship and duty of the State and it should be accessible to all Brazilians, without discrimination. Moreover, it defined that the right to health is not only addressed through actions and health services, but also with economic and social policies capable of increasing the quality of life and reducing the risk of disease and other injuries. Brazilian Federal Law No. 10,741, dated 1 October 2003, called The Statute of the Elderly, provides a range of social and economic policies to improve the quality of life of the elderly and gives SUS full responsibility for the health of that portion of the population 5. More recently, in 2006, the National Health Policy of the Elderly was updated and expanded 6 .

It is important to highlight that this inadequacy of the health system in assisting the elderly is not unique to the public sector; the private sector is also not prepared for an aging population 7 .

This paper aims to add evidences to start thinking about public policies for care to the elderly, in the context of social assistance and health care, describing possibilities for reorganization of the service network from the analysis of examples such as Cristo Redentor Shelter, located in Rio de Janeiro, and initiatives from the services of the Hospital Complex known as "Conceição Hospital Group”, in Rio Grande do Sul, both located in Brazil.
We present the theoretical foundations found in the literature about aging and the context of care to this segment of the population. Then, we present the methodology used in this article, the results of the case studies and, finally, the conclusion and recommendations.

\section{Aging and dependency}

The theoretical approach to this research deals on the dependency concept of Hazzard et al. (1994, apud Caldas ${ }^{8}$ ), Caldas 8 and the Braziilian Ministry of Health 6 . The chronic situation of aging with dependency is underlined by Llera \& Martín (1994, apud Caldas 8) and Pitaud (1999, apud Caldas 8).

In Brazil, the number of elderly (aged 60 and over) increased from 3 million in 1960 to 7 million in 1975 and 14 million in 2002 (an increase of $500 \%$ in forty years), according to Lima-Costa \& Veras 9

We must, therefore, find ways to incorporate the elderly in society, changing concepts that are already deeply rooted and using new technologies like innovation and wisdom, in order to achieve in a fair and democratic way, equity in the distribution of services and facilities to the fastest growing populational group in Brazil 9.

The Brazilian population enters into a sustained process of destabilization of its age structure, with a continued narrowing of the base of the pyramid and therefore the aging of the population (Camarano, 1999, apud Carvalho \& Garcia 10; Wong, 2001, apud Carvalho \& Garcia 10).

The coexistence of generations born before and after the fast decline in fertility, separated around the age of 10 years in 1970; of 20 years in 1991; and of 30 years, in 200010.

\section{Aging and the role of public health service networks}

The issue of health service regionalization also appeared related to financing, supporting the idea of a rationalisation of resources in England during the 1920s 11. The first proposal of a network model for health services was presented by the Dawson Report in England, in 192012.

In 1970, through experiences in the north of Minas Gerais State, namely the PIASS [Programa de Interiorização das Ações de Saúde e Saneamento] and PLUSS [Programa de Localização de Unidades de Serviços], this concept of regionalisation and Service Networks arrived in Brazil 13, but has only been widely spread and consolidated at the beginning of the 21 st Century. It is interesting to see how the concepts used today and 
discussed as gateway, regions, complexity levels, among others, were already defined and clearly delimited in the report of 192012 .

The construction of networks is based on the fact that in a given population, the cases that need attention involving less complex services - or lower technological density are more frequent than those which require greater complexity. Thus, using extreme examples, they are fortunately more common in cases of flu, diarrhea, hypertensive crisis, than in those of brain tumors 12 .

In the specific case of a care network for the elderly, the network is organized in accordance with the dependency degrees, which range from home care to high complexity.

\section{Research method}

This research uses the deductive approach through descriptive case studies. The study is based on secondary and quantitative data, extracted from the databases of the Brazilian Institute of Geography and Statistics (IBGE), from the Ministry of Health and from the existing records in the units studied and from qualitative data, according to the classification of Yin 14, with a focus on the management of health services for the elderly at the Cristo Redentor Shelter in Rio de Janeiro, and the Conceição Hospital Group, in Rio Grande do Sul, both in Brazil.

The methodology adopted is based on a mixture of quantitative and qualitative approaches to meet the objectives of this research, in which the changes in the physical infrastructure and technological units of attention to the elderly, whether in the context of welfare or of health care, the material of previledged study.

In that sense, a brief historical account was prepared for each case study, helping to contextualize and evaluate the institutions and structures. The analysis of the material regarding the physical structure and technology of each institution was based on the method recommended by Donabedian 15 , in which the author characterizes three levels of analysis. The level of analysis used in the research is structure evaluation: it takes into consideration the conditions of physical infrastructure, technological resources and organizational services.

The data obtained by means of documental analysis were treated thematicly, according to their content, seeking to build up a conceptual map with sufficient evidence for the understanding of each experiment examined.

In theory, the health institutions, by implementing new technologies and increasing the quantitative and qualitative supply of services, should change the dynamics of the services that comprise the local/regional and state health systems. Thus, it is expected that the increase in services, the subject of the case study, drive improvements in the current structure of supply towards the constitutional principles of universality and equity.

The choice of levels of analysis was based on the criteria of convenience and opportunity in terms of access to existing databases, considered compatible with the character of exploratory research. The cases are considered relevant regarding the demonstration of two practices for the structuring of care networks to the elderly.

\section{Data presentation}

\section{The Cristo Redentor Shelter}

The Cristo Redentor Shelter is a classic example of using the Hotel Dieu Pavillion Model for the implementation of a shelter for the elderly in Brazil. This shelter is located in the district of Bonsucesso, Rio de Janeiro, occupying $173,000 \mathrm{~m}^{2}$, distributed in 13 pavilions, of which only seven were activated at the time, while three were diactivated and the other three are totally destroyed. There are still about 20 houses intended for support activities.

It is situated in an industrial zone and within the impact area of the Yellow Line; a major urban expressway in Rio de Janeiro, linking several neighborhoods between Barra da Tijuca and Ilha do Fundão, and for these reasons, the shelter is notable for having an area of urban importance.

In 1996, the Cristo Redentor Shelter was a unit of the Ministry of Welfare and Social Assistance (MPAS), previously managed by the now extinct Brazilian Assistance Legion. It is considered the largest shelter for the elderly in Brazil, and its clientele was composed of elderly people who were not able to ensure their own survival.

Between August 1996 and May 1997, the shelter was directly managed by the State University of Rio de Janeiro, with the support from its Open University for the Third Age (UnATI), through an agreement with the MPAS. During this period, besides the daily activities of the Cristo Redentor Shelter, several initiatives were implemented aiming to improve the conditions of institutionalized care for the elderly, which also included a project to restructure the physical functional Asilar Complex 16. 
Cristo Redentor Shelter physical-functional survey

The physical-functional survey of the Cristo Redentor Shelter complex aimed to support the forms of urban and architectural interventions in the physical implementation of Care Programs relevant to the "Integrated Plan of Governmental Action for the Development of the National Policy for the Eldery".

The physical-functional survey was based on the following assumptions:

- Analysis of the physical implantation of the complex facing the spatial demands in attendance for the Integrated Actions of Supporting the Elderly;

- Analysis of the physical and functional architecture of the pavilions with regard to their appropriateness for Functional Programs; and

- Evaluation of infrastructure resources and maintenance systems which are available for the implementation of the physical-functional restructuring.

A mapping has been done by the Technical Management of Projects and Works Office (installed in the Cristo Redentor Shelter since August 1996), aiming to register all buildings, concerning their current situation. The occupation of each building and its administrative linkage was initially identified in order to carry out a zoning of activities.

Establishment of the intervention proposal in the provision of services to the elderly

\section{a) The Director's Plan for the Cristo Redentor Shelter}

The actions undertaken by ETGPO [Escritório Técnico de Gerenciamento de Projetos e Obras] can be subdivided into two large blocks, the first concentrating the actions directed at the general proposal for an intervention in the macro Complex, the Director's Plan for the Cristo Redentor Shelter, and the second block of actions which brings together the punctual interventions developed and the Architectural Projects designed.

\section{b) Working methodology}

Initially, the preliminary architectural programs were formed together with the health and assistance teams in order to identify the spatial demands. After that, an evaluation of the whole building complex was conducted following the general guidelines:

- To prioritize the permanence of the building to minimize the costs with construction;
- To determine the spatial compatibility of the whole building complex to the specific rules regarding health institutions and shelters;

- To condition reforms according to the structural and constructive diagnosis of the existing buildings; and

- To evaluate the topographical problems facing the new proposals from architectural and urban interventions in the complex.

From these results, a general zoning plan was produced for the implementation of the following premises of action:

- Grouping of activities by sectors, the spaces with physical and functional similarities; and

- Service quantifications and qualifications of the architecture and urbanism departments to facilitate the implementation of the Director's Plan for the Cristo Redentor Shelter.

The spatial reformulation of the Cristo Redentor Shelter campus, conditioned by the programs involved in "integrated actions to support the elderly", was based on the diagnosis of the physical-functional situation. The necessity to rethink the zoning, aimed at a set of harmonius occupation that could attend the several space demands by the sectorization of activities has been noticed.

\section{c) Occupation plan}

The proposed occupation plan sought to design an urban spatial structure, usual for a small town, flexible and organic, capable of breaking the existing architectural typology currently composed of rigid and closed spaces. The urbanistic interventions proposed for the areas of leisure and coexistence, aim to redeem the references of citizenship and the elderly right to co-live in a community.

The permanence of the church and its strategic location conditioned the concept of a central community area, referring to the concept of a square, as seen in small towns in the countryside. As a result of this physical aspect, it was also considered the implantation of the Ambulatory and Living Centers in this area, conditioning the revitalization of the original gate, appropriate for the proposed intervention.

The road route preliminarily proposed sought to tailor the original route to its new use, differentiating itself from the flow of pedestrians and cars, proposing a peripheral way surrounding the complex and allowing the movement of vehicles (taxis, ambulances and cars). 


\section{d) Sectorization of activities}

Based on the principles postulated by the occupation plan and zoning, the sectors of the Cristo Redentor Shelter Urban Complex will be identified and characterized.

Sector 1 - Living Center I: this sector adds the activities included in the programmes of the Living Centre. It aims at the shelter interaction with the surrounding community.

Sector 2 - Living Center II: this sector will be allocated to the activities of Occupational Therapy, Education, Leisure and Services.

Section 3 - Creche and Entities: located near the service entrance, this sector adds functions aiming to meet the external public, who keeps a relationship of coexistence with the shelter along the years.

Sector 4 - Sports Area: the project aims to promote the practice of physical activities through the design of an "integrated park for physical activities and leisure" integrated with the Living Center programmes, Health and protected housing.

Sector 5 - Housing/Protected housing: the architectural plan designed for this sector tried to reproduce an urban design which resembles a neighborhood.

Sector 6 - Hospital Support/Protected Housing of Partial and Total Support/Administration: the permanence of the hospital and pavilions juxtaposed to meet the total and partial dependents will encourage the locomotion of nurses and the functional interaction among the hospital activities, such as logistical and technical support.

Sector 7 - Expansion Area: depending on the topographical features of this area, mainly composed of steep slopes, its use can be incorporated to recreation areas in the protected housing by the construction of a large deck.

Sector 8 - Maintenance and Staff Residence: this sector will maintain its unique feature of occupation. In addition to the maintenance workshops existing today, residences for officials will be established. This occupation also aims to enhance security before the invasion occurred along the wall.

Sector 9 - Green Reserve: the Cristo Redentor Shelter has a vast green area, favored by the density of trees and scattered lawns. One urban solution for the large range of area non aedificandi appears as one of the major challenges for a future Urban Project, which is integrating these areas to other existing green areas.

\section{e) Health Care Units}

Hospital Unit: it includes 50 beds for emergency medical complications of low complexity or surgical recovery of an average stay for patients referred by the General Hospital where they suffered complications.

Ambulatory Care Unit: Criteria for operation - open to the community, this unit will carry on the role of a gateway to the Cristo Redentor Shelter. Its operation will happen considering the Care Program for the Elderly in which several sub-programs are inserted, such as: Home Visit, Education in Health, Center for scheduling consultations and examinations, among others.

Day Center: this work is devoted to the prevention of the institutionalization of the user with dementia and it aims to base the development of self-care, through the education process, as well as provide support and rest to the family caretakers.

The Architectural Projects - the question of humanization of the housing area

Next, the architectural projects are presented aiming at humanizing the homes of the semidependent and dependent elderly.

The elderly with greater need will be arranged in beds facing the corridor, easy to see and easy to be accessed by the technical team, the beds next to the wall will be designed for the elderly with more autonomy, because they privilege privacy.

Working together with the health teams, some products were developed to help the internal decoration, such as patchwork, pictures, photos of relatives and friends, paintings, etc.

Its capacity is for 12 people, with living room, dining room, kitchen, three bathrooms and caretaker room. On the outside, there is a service area with sink and washing machine.

Besides the implementation in the Cristo Redentor complex, this type of housing was also foreseen to be implemented in other districts of the city of Rio de Janeiro, which present a significant elderly population, and articulated with the Primary Health Care Units, such as Health Centre Medical Stations.

The discussion involving the consolidation of the space intended as housing for the clients of the Cristo Redentor Shelter, can be regarded as the key process of this project. The necessity for integrating different views from each work team, involving a complete view of eldery needs - social, cultural, health, psychological and spatial means that this process is rich and dynamic.

The diversity in the way each specific team performs having its own objectives and method- 
ologies, enable a new dynamic in the process of thinking out a shelter institution.

The axis of this project leads to a single rationality, a new model of care to the institutionalized elderly, however, this rationality will often be subject to the methodological characteristics intrinsic to each practice area, as in the following proposals:

- Structuring of a Support Health Unit within the Cristo Redentor Complex, giving support to the clinical complications of the institutionalized elderly;

- Structuring of an Ambulatory Care Unit for the institutionalized elderly (clinic segment) and/or the external elderly (preventing sheltering); and

- Structuring a Day Center primarily focused on the integrated care between the activities of Health and Living Center.

\section{The Conceição Hospital Group}

The second case study refers to the reorganization of elderly care in a service network located in the capital of Rio Grande do Sul State. Unlike the previous case, this example searches the management of health care offered as an axis of analysis and using a hospital unit. The analytical approach seeks quite briefly, to recover evidences from the history of hospital care in the current context, where the change in the modeling of care provided to the elderly population is included.

Historical approach: the services of the Conceição Hospital Group and the care offered to the elderly

The Conceição Hospital Group is a complex made up of four specialized hospitals (a general hospital with 882 beds, a pediatric hospital with 252 beds, a traumato-orthopedics hospital with 282 beds and a gyneaco-obstetrics hospital with 189 beds) and a primary health care network with 12 units. It is linked to the Ministry of Health and located in the city of Porto Alegre. Currently, only in the districts of Porto Alegre and Rio de Janeiro such services are kept and directly linked to the Ministry of Health. The Brazilian health system encourages the decentralization of health services to the communities.

The hospital services of this complex provide reference care to the population of Porto Alegre and the metropolitan region, and to a lesser extent to other regions of the state and neighbouring states. The services of primary care are intended to care for a population of 125,000 inhabitants of the north region of Porto Alegre.

Hospital care in Brazil and other countries is characterized by the provision of procedures with great technological sophistication and respond to a duality of power polarized between physicians and administrators 17 .

According to the Ministry of Health 18 , the configuration of the current reality regarding hospital care is the result of a historical process that has several inter-related determinants, ranging from those relating to the development of models of organization and management in health and the redefinition of epidemiological profiles and care practices, the corporate and institutional fields up to the values and social representations of the users in relation to the hospital institution.

The description of the initiative for the institutional reorganization implementing lines of care to the elderly may expand the understanding of the innovations that begin to be produced in terms of hospital care in the SUS in Brazil.

Descriptive approach: an aging population, technological incorporation and the supply of new services by the Conceição Hospital Group

The Brazilian reality as well as the one in Rio Grande do Sul is no exception to the trend identified in international studies, which show a fast aging of the population. As noticed in Table 1, considering data from Brazil and the state of Rio Grande do Sul, there is a significant trend towards an increasing concentration of elderly, when comparing data from the 1980 population census and the population estimates for the year 2007.

For the rate of $6.07 \%$ of population aged over 60 in the country in 1980, a larger percentage in the territorial outline of Rio Grande do Sul (7.21\%) has already been confirmed. This more pronounced trend of growth is maintained in data for 2007. That is, the rate of population aging is greater in the state.

These data indicate significant challenges to the health system, particularly in the field of basic care. Piccini et al. 19, examining the effectiveness in the provision of basic health services and their use by the elderly population in several communities of the country, found indicators of loss of effectiveness in the supply and use of basic care services, with a better performance in services in the Family Health Strategy located in the communities of the south and east regions of the country.

This finding is relevant to the proposition of specific policies for this segment of the population resulting from the observation that home caretakers report difficulties in the organization of qualified care, and these difficulties are minimized with the organization of a network of support involving the health services 20 . 
Comparative study of the number and percentage of the population over 60 years and the total population in several territorial outlines, 1980 and 2007

\begin{tabular}{|c|c|c|c|c|c|}
\hline \multirow[t]{2}{*}{ Territory/Populational outline } & \multicolumn{2}{|c|}{1980 census } & \multicolumn{2}{|c|}{2007 estimate } & \multirow[t]{2}{*}{ Variation (\%) } \\
\hline & $\mathbf{n}$ & $\%$ & $\mathrm{n}$ & $\%$ & \\
\hline \multicolumn{6}{|l|}{ Brazil } \\
\hline Population over 60 years & $7,226,805$ & 6.07 & $15,955,579$ & 8.43 & 2.35 \\
\hline Total population & $119,011,052$ & & $189,335,187$ & & \\
\hline \multicolumn{6}{|l|}{ Rio Grande do Sul } \\
\hline Population over 60 years & 560,774 & 7.21 & $1,147,481$ & 10.36 & 3.14 \\
\hline Total population & $7,773,849$ & & $11,080,322$ & & \\
\hline
\end{tabular}

Source: adapted from Brazilian Ministry of Health (http://www.datasus.gov.br, accessed on 12/Mar/2008).

In the context of these studies, it is possible to notice the need of organizing regional policies to improve health care to the elderly, in particular by implementing innovative methods of primary health care, including regular home care, support to lay caretakers, improvements in home care for the elderly and the provision of specific actions for the elderly and their caretakers as part of primary care.

The fast growing and processing of medicalhospital care that occurred in recent years, and advances in technology - especially in resources for diagnosis and therapy - have caused a disorganized growth in intra-hospital services, that is refleced in the organization of functional health units and aggravated by the solution of continuity among the several administrations during this period.

The story of Conceição Hospital Group is similar to many other major hospital complexes in the country, which mainly from the 1980s suffered the impact of the accelerated process of incorporation of medical/ hospital technologies.

Indeed, the pressure on the expansion of care offered in response to the sole demand of the market is true in the case of the Conceição Hospital Group, since its establishment, through the construction of the Cristo Redentor Hospital in 1956, and its subsequent expansion and construction of the Nossa Senhora da Conceição Hospital and the Conceição Children's Hospital, as well as the incorporation of the Fêmina Hospital in 1973. The management logic that permeated these services, common to that time, was that the increasing supply of services would broaden the quality of care offered and reduce the cost of maintenance. That is, a logic that was focused on the hospital and independent of health system policies. This logic, inconsistent in the face of empirical evidence in the daily administration of these services, remained virtually unchanged even after the incorporation of these to the Ministry of Health, in 1975.

From the 1980s, the disorganized and intensive incorporation of technology in the biomedical area have reached all public and private units on a global scale, in the area of imaging diagnostics for example. There is a big problem when hospitals from the SUS Physics Network, some from the early Twentieth Century, have to start accommodating Tomography, MRI (magnetic resonance imaging), angiography and ultrasonography in previously non existing spaces, since the design of most hospitals in Brazil, Conceição Hospital Group included, considered only the existence of examinations through simple Xray machines.

More recently, from the second half of the 1990s, the hospitals have been 'invaded' by computerisation in all levels and services, aggravating the situation regarding the new areas to be covered by the already existing electrical networks, besides incorporating the logical networks, necessary for the use of Intranet and Internet.

In the specific case of Conceição Hospital Group, we add its state and regional dimension and therefore, a greater need for expansion. Furthermore, the demographic and epidemiological profile of the population of the state of Rio Grande do Sul, as already noted and counting on characteristics of transition and a forecast of acute changes in the next 50 years, generates a complex profile of demands, usually external to the planning of health systems and, above all, of hospital services.

Currently, the changes in the management of Conceição Hospital Group, implemented from 2003, have expanded the relevance of the services that compose the management and social control of the SUS of Rio Grande do Sul, both in care and 
teaching. That is, besides improvements in internal resources and the care offered to the population through SUS, the Group consolidates itself in the production of technology management for public health. Above all, it is involved in searching integration with the systems of health, meeting the Ministry of Health guidelines and, in particular, of the national policy for hospital care.

\section{Conclusion and recommendations}

This paper presented two case studies, two alternative solutions to confront the problem, two paths for isolated initiatives, and if implemented and evaluated, they can gain credibility in the scientific environment and society, and they can be legitimated as public policies focus on the elderly care.

The two cases illustrate the necessity to evaluate the results, effects and impacts of the projects focused on the real problems faced by society, and if diagnosed by planners and managers of the SUS, need indicators to measure the results achieved, both in relation to the efficiency with which the investments were made and, in particular, the effects of the projects in the organization of services, in the care of the population and, especially, the impact on the quality of life of the elderly, the main concern of the initiatives.

There is undeniably an urgent necessity to think about policies focused on home care in order to reduce the risks in housing, since domestic accidents such as femur or pelvis fractures and aneurysms (bruises to the head) are reasons for long-staying admissions and high costs, these ac- cidents could be completely avoided if an action of the Family Health Program was implemented to reduce the risks to the elderly inside the home; the action is known as Healthy Housing.

It is also undeniable that the events of trauma in the elderly, with major impact on expenses concerning health occur on public routes, due to the inapropriateness of cities for the elderly, which demands an urgent intersectoral policy between the Ministry of Health and the Ministry of Cities.

Furthermore, it is urgent for the government to focus attention on the lonely elderly, indigent or not, based on intersectoral efforts and thereby find solutions that can be quickly implemented, with dignity and respect for the elderly.

In the European Community, a similar alternative has been the installation of flats for the elderly and used in countries with sun and sea. This is a solution aimed at the middle and high classes because services are consumed with expressive values. In Rio de Janeiro, an ancient hotel was remodeled on Copacabana beach under the same proposal, a flat for the wealthy elderly. But, what about the elderly poor who often dependent on the SUS? How is the elderly in the middle-class? Who will take care of our elderly in the $21^{\text {st }}$ Century?

Although not implemented in its totality, the Cristo Redentor Shelter project leaves an open way to deal with the issue of housing for the independent elderly, the protected housing inserted into sets of low income housing, or inserted in middle-class neighborhoods and coordinated with Primary Health Care Units, as shown throughout the article.

\footnotetext{
Resumo

Confirma-se, no Brasil, uma tendência mundial do envelhecimento populacional. A sociedade brasileira passa por intenso processo de transformação, onde adultos jovens aparecem cada vez em menor número, cabendo a reflexão: quem vai cuidar dos nossos idosos no século XXI? A estruturação de redes de atenção à pessoa idosa é urgente, abrangendo cuidados primários, incluindo cuidados com a moradia: habitação saudável, garantindo acesso aos níveis secundário e terciário de cuidados, proporcionando diagnóstico precoce e rápido acesso ao tratamento. Este artigo relata duas experiências brasileiras: a reestruturação de um abrigo de idosos indigentes, com 500 internos
}

no Rio de Janeiro, onde foi realizado um amplo processo de humanização, com forte componente reestruturação física das edificações de 1930; e o processo de organização da linha de cuidado de atenção ao idoso no Grupo Hospitalar Conceição, no Rio Grande do Sul, complexo de atenção à saúde com unidades de saúde diversificadas, englobando todos os momentos da atenção: dos cuidados primários ao mais complexo tratamento hospitalar.

Administração de Serviços de Saúde; Serviços de Saúde para Idosos; Saúde do Idoso 


\section{Contributors}

L. R. Pessôa wrote the paper and collaborated in constructing the cases. M. Ferasso wrote the paper. L. M. Vargas contributed in preparing the paper and in it is overall revision. A. A. Ferla collaborated in constructing the cases and reviewed the paper.

\section{References}

1. Lebrão ML, Duarte YAO. SABE - Saúde, Bem-estar e Envelhecimento. O Projeto SABE no município de São Paulo: uma abordagem inicial. Brasília: Organização Pan-Americana da Saúde; 2003.

2. Sostisso RC. Vivências do cuidador no processo de cuidar seu familiar idoso [Trabalho de Conclusão de Graduação]. Caxias do Sul: Departamento de Enfermagem, Universidade de Caxias do Sul; 2006.

3. Degasperi IR. Sexualidade, idoso e cuidado em saúde: encontros e desencontros no cotidiano da atenção em HIV/AIDS [Trabalho de Conclusão de Graduação]. Caxias do Sul: Departamento de Enfermagem, Universidade de Caxias do Sul; 2007.

4. Brasil. Constituição da República Federativa do Brasil. https://www.planalto.gov.br/ccivil_03/ Constituicao/Constituicao_Compilado.htm (accessed on 20/Feb/2008).

5. Brasil. Lei Federal $n^{\circ}$. 10.741, de 1 de outubro de 2003. Dispõe sobre o Estatuto do Idoso e dá outras providências. http://www.planalto.gov.br/ ccivil_03/Leis/2003/L10.741.htm (accessed on 20/ Feb/2008).

6. Ministério da Saúde. Envelhecimento e saúde da pessoa idosa. Brasília: Ministério da Saúde; 2006. (Caderno de Atenção Básica, 19).

7. Veras RP. $\mathrm{O}$ anacronismo dos modelos assistenciais na área da saúde: mudar e inovar, desafios para o gestor contemporâneo. O Globo Online 2006; 22 set. http://oglobo.globo.com/opiniao/mat/ 2006/09/22/285798584.asp (accessed on 12/Mar/ 2008).

8. Caldas CP. Envelhecimento com dependência: responsabilidades e demandas da família. Cad Saúde Pública 2003; 19:773-81.

9. Lima-Costa MF, Veras R. Saúde pública e envelhecimento. Cad Saúde Pública 2003; 19:700-1.

10. Carvalho JAM, Garcia RA. O envelhecimento da população brasileira: um enfoque demográfico. Cad Saúde Pública 2003; 19:725-33.

\section{Acknowledgements}

M. Ferasso wishes to thank the CNPq for financial support through a graduate scholarship in Brazil. L. R. Pêssoa wishes to thank Dr. Renato Peixoto Veras, Coordinator of Partnership MPAS/UERJ, for permission in using images and her team of Architects at the Technical Office of Project Management and Works: Luisa Regina Pessoa (coord.), Ildary Mesquita Machado, Leonardo Jacques da Costa Braga, Marcelo Braga, Paulo Levier (in memoriam), Valéria Veras and Walter Teixeira Filho.

11. Ferla AA, Pessôa LR, Carvalho AI, Geyer LMC, Ribeiro CDM, Braga LJC. Financiamento e regionalização em saúde: a experiência gaúcha. Divulg Saúde Debate 2001; (23):52-71.

12. Kusnhir R. Organizando redes de serviços de saúde. In: Pessôa LR, Pinto LF, organizadores. Curso de aperfeiçoamento em gestão de projetos de investimentos em saúde. Rio de Janeiro: Escola Nacional de Saúde Pública Sergio Arouca, Fundação Oswaldo Cruz; 2006. p. 95-113.

13. Pessôa LR. Mergulho em Montes Claros: desafios da alocação de recursos na Rede SUS [Tese de Doutorado]. Rio de Janeiro: Escola Nacional de Saúde Pública Sergio Arouca, Fundação Oswaldo Cruz; 2005.

14. Yin R. Estudo de caso: planejamento e métodos. $3 a$ Ed. Porto Alegre: Bookman; 2005.

15. Donabedian A. Explorations in quality assessment and monitoring. Volume I: the definition of quality and approaches to its assessment. Ann Arbor: Health Administration Press; 1980.

16. Veras RP. A reestruturação do Abrigo Cristo Redentor: o macro asilo transformado em uma mini cidade. Physis (Rio J.) 1997; 7:85-104.

17. Carapinheiro G. Saberes e poderes no hospital: uma sociologia dos serviços hospitalares. Porto: Afrontamento; 1998.

18. Ministério da Saúde. Reforma do sistema da atenção hospitalar brasileira. Brasília: Ministério da Saúde; 2004.

19. Piccini RX, Facchini LA, Tomasi E, Thumé E, Silveira DS, Siqueira FV, et al. Necessidades de saúde comuns aos idosos: efetividade na oferta e utilização em atenção básica à saúde. Ciênc Saúde Coletiva 2006; 11:657-67.

20. Rodrigues MR, Almeida RT. Papel do responsável pelos cuidados à saúde do paciente em domicílio - um estudo de caso. Acta Paul Enferm 2005; 18: 20-4.

Submitted on 18/Nov/2009

Final version resubmitted on 02/Mar/2010

Approved on 29/Mar/2010 